\title{
Sex, Gender, and Refugee Protection in Canada under Bill C-11: Are Additional Protections Required in Light of In re R-A-?
}

\author{
Chantal Tie
}

\section{Abstract}

This case comment takes a critical Canadian look at gender-based refugee claims in light of the recent United States Board of Immigration Appeals decision in re R-A-. The author points out that many of the obstacles for women who are refugee claimants in the United States, which are highlighted in re R-A-, also exist in Canada. She argues that when we are forced to define women's gender persecution as persecution on account of "membership in a particular social group," analytical problems are inevitable. These problems arise because our refugee definition does not acknowledge that women are persecuted worldwide simply because of their gender. The author urges that gender persecution be specifically included in the Canadian refugee definition, to bring the definition in line with other domestic and international human rights instruments, which already recognize the importance of women's human rights.

\section{Résumé}

Cette étude de cas porte un regard critique canadien sur les demandes d'asile basées sur des considérations de sexe à la lumière de la décision récente de la Section d'Appels de la Commission sur l'immigration des États Unis dans l'affaire re R-A-. L'auteure souligne que beaucoup des obstacles confrontant les femmes revendiquant le statut de réfugié aux États Unis, et qui ont été mis en exergue dans l'affaire re R-A-, sont aussi présents au Canada. Elle soutient que lorsqu’on est forcé de définir la persécution sexiste des femmes comme persécution du fait de «l'appartenance à un groupe social », des problèmes analytiques sont inévitables.

Ces problèmes surgissent parce que notre système de détermination ne veut pas accepter la réalité que les femmes sont persécutées dans le monde entier du fait même de leur sexe. L'auteure demande que la persécution sexiste soit incluse dans la définition canadienne du droit d'asile, afin d'harmoniser cette définition avec d'autres protocoles des droits de la personne au niveau national et international, qui reconnaissent déjà l'importance des droits de la personne des femmes.

I n September of last year, one of the demands made to the Canadian government by the World March of Women was that persecution based on gender be included as a ground for claiming refugee status in Canada under the Immigration Act. ${ }^{1}$ Despite requests by women's organizations across Canada for the explicit inclusion of this protection, an overhaul of our immigration and refugee law contained in Bill C-31 (which died on the Order Paper with the election call last fall) and the new Bill C-11 preserve the refugee definition in the proposed new Immigration and Refugee Protection Act. ${ }^{2}$ When members of the Canadian Women's March Committee met with Citizenship and Immigration Minister Elinor Caplan to discuss the Women's March demands in October of last year, she rejected out of hand any amendment of the refugee grounds to make them more inclusive, confident that the Canadian gender guidelines and current legal in- 
terpretations from our courts provide adequate protection for refugee women fearing gender-based persecution. ${ }^{3}$

Over the past twenty years there have been significant advances in feminist legal thought and scholarship. A critical examination of refugee law from a feminist perspective would have been unthinkable at the time of the drafting of the 1951 un Convention relating to the Status of Refugees, or the 1967 Protocol. Indeed, even by 1988 , the date of publication of the UN Handbook on Procedures and Criteria for Determining Refugee Status, no mention was made of women, sex, or gender as grounds for being recognized as Convention refugees, despite the fact that women and children have always represented the majority of the world's refugees, ${ }^{4}$ and women's refugee experiences can be markedly different from those of men.

In addition to those women who are officially counted as refugees in the refugee camps or claiming refugee status around the world, there are countless others who are routinely tortured, beaten, humiliated, mutilated, imprisoned, and even murdered by their spouses. This occurs in some cases with state sanction, in other cases when the state is unable or unwilling to provide protection, or where the state has abdicated responsibility for the protection of women. Extreme domestic violence is one of the most widespread human rights violations committed against women, committed against women of all national, ethnic, and social origins, from all economic conditions.

Despite the fact that women comprise the majority of the world's refugees and that their refugee experience is different from the male refugee experience, it is only recently that the magnitude and the specificity of women's refugee experience has begun to be acknowledged.

In 1991 the United Nations High Commissioner for Refugees adopted guidelines for the protection of refugee women. ${ }^{5}$ In the following year, in Canada, a Saudi woman identified by the pseudonym "Nada" was denied refugee status, but her case became the rallying point and eventually the catalyst for change in the treatment of genderbased refugee claims. ${ }^{6}$ The strength of public support for Nada, together with a growing international recognition of the nature of women's persecution, led to the introduction of gender guidelines in Canada for the interpretation of the refugee definition.? These guidelines permit an interpretation of the refugee definition in a way that incorporates the gender-related claims of women into the enumerated grounds in the Convention. Other Western countries have followed Canada's example of issuing non-binding gender guidelines, while maintaining the original enumerated grounds for claiming refugee status in the Convention. In 1995, the us Department of Justice issued gender guidelines (DOJ guidelines) for officers adjudicating women's asylum claims, publicly acknowledging the Canadian lead. ${ }^{8}$

Both Canada and the United States chose to address gender concerns without amending the refugee definition to include gender or sex as a ground for claiming refugee status. In both jurisdictions the refugee definition is incorporated into domestic legislation, making change possible at the domestic level, but such change has never been likely to be politically acceptable to the electorate. Those who oppose opening the definition to add gender or sex argue that to do so would constitute an open invitation to those who wish to narrow the existing definition. Like the Canadian Minister of Citizenship and Immigration, they argue that such a risk is not warranted when the existing definition is subject to an interpretation that recognizes claims based on gender.

Notwithstanding this optimism, there remain a number of analytical difficulties that arise in gender-based claims when we try to fit the specificity of gender persecution into the existing categories of refugee persecution. Because the definition has not been amended to add sex or gender, claimants must show that their persecution is "on account of" their political opinion, race, nationality, or religion, or because of membership in a particular social group. These difficulties were recently starkly highlighted in the American Board of Immigration Appeal case In re R-A-. Notwithstanding us Attorney General Janet Reno's vacation of the decision in the last days of the Clinton administration, the case should serve as a wake up call to other jurisdictions that have adopted non-binding guidelines to address issues raised by gender-based refugee claims.

In re $R-A-$, a majority of ten members sitting on the Board of Immigration Appeals (BIA) overturned the refugee acceptance of a Guatemalan woman under circumstances where they acknowledged the "heinous abuse she suffered and still fears from her husband in Guatemala." The credibility of the claimant was unimpeached, and the litany of torture and abuse she recounted, both physical and sexual, from her violent and domineering husband were fully accepted by the Immigration judge at first instance. These findings were undisturbed on appeal.

Indeed, the BIA stated, "We struggle to describe how deplorable we find the husband's conduct to have been," and, "The respondent in this case has been terribly abused and has a genuine and reasonable fear of returning 
to Guatemala."9 On the facts proven at the original hearing, the BIA was prepared to accept that the treatment experienced was "persecution," and the claimant had made serious efforts to seek state protection, including complaints to the police and court applications, which had proved fruitless. The difficulty for the board arose, however, because the claimant failed, in their view, to demonstrate a link between her persecution and any perceived or imputed political opinion, or because of her membership in any particular social group.

The In re $R$ - $A$ - case was highly controversial, in the general media and within the refugee community. Scholars criticized the findings of the board and claimed that its decision brought into question the commitment of Immigration and Naturalization to its own gender guidelines and raised serious concerns about the nature and scope of protection for victims of gender-based persecution. ${ }^{10}$ Karen Musalo, director of the Center for Gender \& Refugee Studies in the United States, commented,

The decision in re R-A- also goes against a number of significant developments and trends. It is counter to the principles expressed in the INs Gender Guidelines, inconsistent with the Board's own decision in Kashinga, contrary to the jurisprudence of countries such as Canada and the United Kingdom, and a repudiation of fundamental understandings regarding the nature of women's human rights, and the relationship between these rights and principles of asylum. ${ }^{11}$

In this case comment, I start from the premise that the BIA decision in $r e R$ - $A$ - was incorrect and that the strong dissent sets out a preferable interpretation of the law that relies upon domestic law, international human rights instruments, and the United States DoJ guidelines. While this comment discusses some of these interpretation issues, they are not the primary focus. Instead, I am more interested in what this decision would have meant for women seeking protection from severe spousal abuse if it had not been vacated, or if the interpretation of the definition employed gains wider acceptance. Were the barriers the BIA erected so high that they are insurmountable for most refugee claimants seeking protection from severe spousal abuse? Are women seeking protection from spousal abuse at peril of a similar setback here in Canada?

\section{The Immigration Judge's Decision}

The Immigration judge found that the claimant was a member of the social group of "Guatemalan women who have been involved intimately with Guatemalan male companions who believe that women are to live under male domination." She found this group was both cognis- able and cohesive, as members shared the common and immutable characteristics of gender and the experience of having been intimately involved with a male companion who practices male domination through violence. Further, the judge found that when the claimant resisted her husband's violent acts, she demonstrated the political opinion "that women should not be dominated by men," and that her husband was motivated to commit the abuse because of the political opinion he believed her to hold. ${ }^{12}$ On appeal to the BIA, both of these findings were overturned.

\section{The вIA Decision: Political Opinion}

The BIA rejected the basis of the claimant's refugee claim upon political opinion, finding that her actions did not illustrate a political opinion-implied or imputed-as there was no evidence that her husband was motivated to harm her on the basis of any political opinion. Because she failed to articulate a political opinion, they were not convinced that she even had a political opinion at all. The Immigration Appeal Board noted,

At the onset, the respondent never testified that she understood the abuse to be motivated by her political opinion or membership in a group of any description. Her husband never articulated such motivation, and she does not seem to have perceived it independent of the legal arguments now being advanced on her behalf. The dissent itself does not claim that either the respondent or her husband understood the abuse to be motivated, even in part, by the respondent's political opinion or social group membership. ${ }^{13}$

The record indicates that the respondent's husband harmed the respondent regardless of what she actually believed or what he thought she believed...

The respondent's account of what her husband told her may well reflect his own view of women and, in particular, his view of the respondent as his property to do with as he pleased. It does not, however, reflect that he had any understanding of the respondent's perspective or that he even cared what the respondent's perspective may have been. According to the respondent, he told her, "You're my woman and I can do whatever I want," and, "You're my woman, you do what I say," and that he "would hit or kick me whenever he felt like it."

Nowhere in the record does the respondent recount her husband saying anything relating to what he thought her political views to be, or that the violence towards her was attributable to her actual or imputed beliefs. Moreover, this is not a case where there is meaningful evidence that this respondent held or evinced a political opinion, unless one assumes that the common human desire not to be harmed or abused is in itself a "political opinion." The record before us 
simply does not indicate that the harm arose in response to any objections made by the respondent to her husband's domination over her. Nor does it suggest that his abusive behaviour was dependent in any way on the views held by the respondent. Indeed, his senseless actions started at the beginning of their marriage and continued whether or not the respondent acquiesced in his demands. The record reflects that, once having entered into this marriage, there was nothing the respondent could have done or thought that would have spared her (or indeed would have spared any other woman unfortunate enough to have married him) from the violence he inflicted. ${ }^{14}$

To accept that R-A-'s resistance, made manifest by her flight from abuse and her search for help and protection, is the expression of a political opinion requires one to understand the role that violence against women plays in the perpetuation of a male-dominated society. Unfortunately, it is only recently that domestic violence has been recognized explicitly as a human rights issue. Human Rights Watch, in its Brazilian report in 1991, charged for the first time that a state was complicit in the crime of domestic violence because of its failure to prosecute it equally with other crimes, and to guarantee women the fundamental civil and political right to equal protection before the law without regard to sex.15 In the broader sense, women's struggle to overcome the social, legal, and cultural barriers to equality has been waged with a developing appreciation for the role that violence plays in the maintenance of a male-dominated society. If one has an appreciation of this context, and actually accepts it, then the refugee claimant's flight from her abusive husband can be characterized as the expression of a political opinion.

As Rhonda Copeland points out,

Indeed, domestic violence against women is systemic and structural, a mechanism of patriarchal control of women that is built upon male superiority and female inferiority, sex-stereotyped roles and expectations, and the economic, social and political predominance of men and dependency of women. While the legal and cultural embodiments of patriarchal thinking vary among different cultures, there is an astounding convergence in regard to the basic tenets of patriarchy and the legitimacy, if not necessity, of violence as a mechanism of enforcing that system. ${ }^{16}$

Notwithstanding the BIA comments, there was ample evidence upon which the BIA could have found the necessary connection between the political opinion and the actions of the abuser. Indeed, the BIA even touched on some of these connections when they stated, "There is little doubt that the respondent's spouse believed that married women should be subservient to their own husbands ...
On the basis of this record, we perceive that the husband's focus was on the respondent because she was his wife." Clearly these statements indicate the spouse's view of the reason he believed he could abuse her. If that were not enough, the dissent added further facts from the record that should have been sufficient to situate the persecution in a political context:

First, to assess motivation, it is appropriate to consider the factual circumstances surrounding the violence. The factual record reflects quite clearly that the severe beatings were directed at the respondent by her husband to dominate and subdue her, precisely because of her gender, as he inflicted his harm directly on her vagina, sought to abort her pregnancy, and raped her. ${ }^{17}$

These factual findings underpinned the dissent's analysis which led them to conclude that domestic violence is also a means by which men may systematically destroy the power of women-a form of violence rooted in the economic, social, and cultural subordination of women.

\section{The Claimant's Failure to Articulate a Political Opinion}

Traditionally it was thought that "political opinion" applied only to those who had formal membership in a political party. ${ }^{18}$ However, in recent years we have adopted the more general interpretation advocated by GoodwinGill as "any opinion on any matter in which the machinery of state, government, and policy may be engaged." ${ }^{19}$ We have also recognized that the political opinion need not have been expressed, but can be perceived from the claimant's actions. ${ }^{20}$ Notwithstanding this expanded definition, in determining these claims there has always been a focus on establishing the political opinion in the first place. Even the UNHCR handbook notes,

It will, therefore, be necessary to establish the applicant's political opinion, which is at the root of his behaviour, and the fact that it has led or may lead to the persecution that he claims to fear. ${ }^{21}$

This requirement to root out the political opinion of the claimant led the BIA to require the articulation of the political opinion by both the claimant and her abuser. But realistically, how many women who are victims of domestic violence, particularly those coming from countries where feminist scholarship and discussion are not important components of the national debate, can be expected to articulate the significance of their personal situation in this wider political context? How many people 
are able to transcend learned patterns of behaviour, to be able to view individual behaviour in its broader social, political, or cultural context? Moreover, how many Immigration judges, board members, or members of the Board of Immigration Appeals would be familiar with such theories, much less accept them?

There is no doubt that part of the board's difficulty in characterising the claimant's actions as political stems from the traditional understanding that political acts are intimately linked to public acts. Actions that are understood to be political-both express and implied-take place publicly, like organizing election rallies, running for office, or expressing opinions on matters of state importance or the rights of citizens or workers. However, escape from domestic abuse is rarely a public act and, significantly, a woman's defiance of male authority in the home is rarely seen as political.

As Doreen Indra commented in a previous Refuge article,

The key criteria for being a refugee are drawn primarily from the realm of public sphere activities dominated by men. With regard to private sphere activities where women's presence is more strongly felt, there is primarily silence-silence compounded by an unconscious calculus that assigns the critical quality "political" to many public activities but few private ones. Thus, state oppression of a religious minority is political, while gender oppression at home is not. ${ }^{22}$

The Board of Immigration Appeals clearly characterized the harm suffered by the claimant as a private harm, emphasizing how the abuse was directed against only the claimant, not against other members of the public:

[T] he respondent fails to show how other members of the group may be at risk of harm from him ... but the record indicates that the respondent suffered and feared intimate violence only from her own husband ... On the basis of this record, we perceive that the husband's focus was on the respondent because she was his wife, not because she was a member of some broader collection of women, however defined, whom he believed warranted the infliction of harm .. . Importantly, construing private acts of violence to be qualifying governmental persecution, by virtue of the inadequacy of protection, would obviate, perhaps entirely, the "on account of" requirement in the statute. ${ }^{23}$

To emphasize the private nature of the harm, the Board of Immigration Appeals went to great lengths to decontextualize the behaviour of the claimant's husband, removing it entirely from the social and cultural context within which he lived and which nourished his male dominance. Ultimately, the BIA attributed the violence solely to the abnormality of the abuser:
Other factors, ranging from jealousy to growing frustration with his own life to simple unchecked violence tied to the inherent meanness of his personality, are among the explanations or motivations that may reasonably be inferred on this record for the actions of the respondent's husband. For example, when the respondent resisted her husband's demands for sexual relations, he would accuse her of seeing other men. Notably, he did not accuse her of harbouring opinions hostile to his own or of being part of an abhorrent group. $^{24}$

What this analysis ignores is that domestic violence is hardly gender-neutral, being overwhelmingly initiated by men against women. The very extent of the abuse-in frequency and universality - attests to the underlying social origins and clearly suggests that it cannot be explained by a narrow examination of the abuser, or even the abused. As the United Nations has noted,

There is no simple explanation for violence against women in the home. Certainly, any explanation must go beyond the individual characteristics of the man, the woman and the family to look at the structure of relationships and the role of society in underpinning that structure. In the end analysis, it is perhaps best to conclude that violence against wives is a function of the belief, fostered in all cultures, that men are superior and that the women they live with are their possessions or chattels that they can treat as they wish and as they consider appropriate..$^{25}$

In the final analysis, the test for political opinion, and for "on account of" political opinion articulated by the board, constitutes an almost insurmountable hurdle for most victims of spousal abuse. Not only must they prove that they have suffered the abuse and that no state protection is available, they must also be able to fully situate their abuse within the overall political context of their own society and have communicated this sophisticated analysis to their spouse. In other words, they would need to be familiar with feminist scholarship, which argues that in a sexually unequal society, physical and sexual coercion that is based in an institution, such as the family, is an abuse of social and sexual power and is used to underscore women's inferiority to men. Indeed, such a requirement would make mandatory reading of Susan Brownmiller's Against Our Will: Men, Women, and Rape for female refugee claimants. ${ }^{26}$ It may not be enough that Canadian courts have recognized the relationship between violence against women and the inequality of the sexes, if the woman herself does not understand the relationship. ${ }^{27}$

The individual refugee claimant must therefore be able to articulate the symbolic significance of her resistance to 
or flight from abuse, within the context of her own profoundly discriminatory society, which fails to guarantee her the civil and political right of equal protection before the law. Not only must she have understood her individual predicament within this context, she must also have somehow communicated her analysis to her persecutor, so that there is a clear link between his abuse and her political opinion, because the abuse must be "on account of" the political opinion.

What makes this scenario even more incredible is what we know about the dynamics of spousal abuse itself. It has been widely documented that the long-term effects of prolonged physical and psychological abuse include low self-esteem, lack of initiative, and passivity, belief that the husband is all-powerful, depression, anxiety, and suicidal ideation..$^{28}$ As Leanne Walker documents, most battered women strive to avoid conflict or provoking anger in their abusers, a strategy that is incompatible with the type of political discussions the Immigration Appeal Board seems to require:

Often a woman may erroneously take responsibility for starting a battering incident because she said something that she should have known would provoke or anger the man. Most battered women believe that if only they could close their mouth when the man is tense, they would not be battered. ${ }^{29}$

The notion that a woman in this situation would actually confront her abusive spouse with her political analysis of his abuse, and then provide him with the opportunity to abuse her as a direct consequence of her political analysis, is patently absurd.

\section{The віА Decision: Membership in a Particular Social Group}

In finding that R-A- was not part of the particular social group of "Guatemalan women who have been involved intimately with Guatemalan male companions, who believe that women are to live under male domination," the BIA was particularly concerned with whether this group had "a voluntary associational relationship."

Moreover, regardless of Ninth Circuit law, we find that the respondent's claimed social group fails under our own independent assessment of what constitutes a qualifying social group. We find it questionable that the social group adopted by the Immigration Judge appears to have been defined principally, if not exclusively, for purposes of this asylum case, and without regard to the question of whether anyone in Guatemala perceives this group to exist in any form whatsoever. The respondent fits within the proposed group.
But the group is defined largely in the abstract. It seems to bear little or no relation to the way in which Guatemalans might identify subdivisions within their own society or otherwise might perceive individuals either to possess or to lack an important characteristic or trait. The proposed group may satisfy the basic requirements of containing an immutable or fundamental individual characteristic. But, for the group to be viable for asylum purposes, we believe there must also be some showing of how the characteristic is understood in the alien's society, such that we, in turn, may understand that the potential persecutors in fact see persons sharing the characteristic as warranting suppression or the infliction of harm ...

The respondent has shown neither that the victims of spouse abuse view themselves as members of this group, nor, most importantly, that their male oppressors see their victimized companions as part of this group. ${ }^{30}$

The board found that the four groups explicitly protected from persecution (on the grounds of race, religion, nationality, and political opinion) exhibit characteristics that typically separate factions within countries; are recognized as groupings in a particular society; comprise members who understand their affiliation; and others in that society understand the affiliation. ${ }^{31}$ Not surprisingly, when the board applied these criteria to the social group defined by the claimant in $R-A-$, they found that it could not qualify as a social group.

What is particularly disturbing about this finding is that it makes public acknowledgement a precondition for recognition of a "particular social group" under the refugee definition. Public acknowledgement of spousal abuse has been extremely slow in coming, making this a significant hurdle for many refugee women. In cases of spousal abuse women often hide their shame, hospitals do not record or report their injuries, police do not charge and the judiciary do not prosecute or convict the offenders. Because police don't take or act on complaints and abusers are not charged or convicted, the abuse is both socially unacknowledged and statistically undocumented. Where there is nothing but denial and silence surrounding spousal abuse, how can there be social recognition of a group's existence, or any battered woman's place in that group?

It is perhaps the final irony for refugee claimants who are women seeking protection from spousal abuse, that these women cannot, and will probably never be able to satisfy the "voluntary associational" criteria required by In re $R$ - $A$ - to prove membership in a social group. Spousal abuse is invisible in many countries such as Guatemala, where domestic assault and abuse are treated as private matters, and men are free to batter and abuse their 
spouses with impunity. Unfortunately, ignorance of the extent of spousal abuse most likely goes hand in hand with a lack of support for female victims of spousal violence. How under these social conditions, where the problem of domestic violence is not even acknowledged, can any claimant ever show that there is social recognition of the group?

Further, it is widely acknowledged in the psychological literature on domestic violence that jealousy, overpossessiveness, and intrusiveness on the part of the abuser tend to lead directly to the social isolation of battered women:

She may cease normal social activities, stop seeing her friends and family, and become a prisoner in her own mind, sometimes without even needing to actually lock the door, although it is not unusual for the batterer to lock her in the house without easy access to a telephone ... The abuser attempts to cut her off from "the world at large," from social supports and resources, and from people or organizations to whom she might turn for help, understanding or solace. If she is permitted social contacts, the abuser controls who they are and monitors all aspects of the contacts. Increasingly isolated, the woman becomes more vulnerable to the abuser...

The isolation that many battered women experience has many sources. Batterers tend to impose isolation on their partners in order to keep power and control, to calm their own fears of abandonment and feelings of intense, irrational jealousy, and to make it less likely that the victim will be able to report the "secret" or find help. A battered woman may believe that the less she and her abusive partner go out into the world of other people, the less likely some social event will trigger another violent outburst. Even when she has a career in which she appears to function well, a battered woman may feel estranged from other people. ${ }^{33}$

The expectation that a group, whose very persecution is achieved and maintained through the imposition of extreme social isolation, would have developed a collective consciousness and social presence within the persecutor society, is simply unrealistic. To make the measure of the group's very existence contingent upon social recognition, is to create an almost insurmountable barrier for those women fleeing domestic violence.

Quite understandably, most claimants like R-A- will probably never have articulated resistance in a traditional political manner, nor have acted in concert with other women opposed to the same or similar abusive practices. It is probably also true for most women fleeing spousal abuse that they are unaware that they are "a member of a particular social group." The irony is that those women seeking protection from societies that provide the least protection for women are predictably the same societies where the level of consciousness and social group recognition for abused women will be at its lowest. This leaves the most vulnerable women with the least protection.

It is worth noting that the BIA also made some disturbing comments preliminary to their main decision, on the failure of the us Congress to change the refugee definition or the asylum statute at the time of the enactment of other relief for women living in, or seeking to escape from, abusive relationships:

The existence of derivative refugee status for spouses, as well as these non refugee provisions for battered spouses, raises the question of whether Congress intended or expected that our immigration laws, even in the refugee and asylum context, would cover battered spouses who are leaving marriages to aliens having no ties to the United States. ${ }^{34}$

The failure to specifically amend the refugee definition to include gender or sex, was seen as evidence that Congress had no intention of changing the definition to include them.

\section{New Immigration Regulations in the United States}

Fortunately, following the In re $R$ - $A$ - decision, the American Department of Justice moved to amend the Immigration and Naturalization Service regulations to "clarify" membership in a particular social group criteria and to "remove certain barriers" to the recognition of spousal abuse claims that arose in light of in re $R-A-$. The proposed new rules cover a wide variety of issues related to gender persecution, including social group membership, nexus, the meaning of persecution, state action, and burden of proof. The commentary on $R-A$-, however, accepts the BIA analysis of political opinion and focuses solely on the shortcomings of the social-group findings in that case:

The Board's analysis of the political opinion claim is consistent with long-standing principles of asylum law and is not altered by this rule. The Board reasoned that the abuse in this case was not on account of the applicant's political opinion because there was no evidence that the applicant's husband was aware of the applicant's opposition to male dominance, or even that he cared what her opinions on this matter were. Rather, he continued to abuse her regardless of what she said or did. This portion of the decision is consistent with the Supreme Court's reasoning in Elias-Zacharias, supra, and with the Board's own precedent that harm is not 
on account of political opinion when it is inflicted regardless of the victim's opinion rather than because of that opinion. ${ }^{35}$

The proposed regulations would, however, alter the "on account of" social group analysis undertaken by the BIA. The BIA found the violence that R-A- experienced was not "on account of" her membership in a particular social group, because there was no evidence that her husband would harm other women who live with other abusive partners. The proposed rules suggest that such group targeting may arise in some cases, but it is not required as a matter of law. Indeed, in some cases a persecutor may target a victim because of a shared characteristic, even though the persecutor acts against only the one victim. The new rule makes the existence of multiple victims with the same group characteristics relevant, but not required.

The final hurdle the rules address is societal recognition of the group as a prerequisite to finding a "particular social group" under the refugee definition. The BIA found the claimant had not shown that the group she said she belonged to "is a recognized and understood to be a societal faction, or is otherwise a recognized segment of the population within Guatemala." When one is addressing this issue, the proposed rules suggest that it is relevant to consider whether there is evidence "about societal attitudes toward group membership or about harm to group members, including whether the institutions of the society at hand offer fewer protections or benefits to members of the group than to other members of society."

This approach breathes life into the evidence introduced in re $R$-A- (which was ignored by the majority of the BIA) that the police did not respond to her calls for help; that she appeared before a judge, but he told her he would not interfere in domestic disputes; and that Guatemalan society still tends to view domestic violence as a family problem. This evidence illustrates that because the claimant possesses a particular characteristic, harm inflicted on her may be tolerated by society, while it would not be tolerated if inflicted on other members of society.

Overall, the proposed regulations are certainly an improvement, as the incorporation of these important principles into regulations ensures their application in refugee claims, in a manner which was never assured with the non-binding gender guidelines. However, the proposals fall disappointingly short of resolving some of the underlying problems in gender-based refugee claims. Indeed, the new regulations specifically avoid creating a categorical rule that a victim of domestic violence is or can be a refugee on account of that experience or fear, preferring a case-by-case approach. ${ }^{36}$ Further, they fail to recognize gender alone as a qualifying category of "particular social group," so that the difficulties inherent in defining particular social group can be expected to persist.

\section{Implications here in Canada}

What are the implications of the $R$ - $A$ - decision for us here in Canada? How well have our gender guidelines worked, and are we at peril of a similar setback? Fortunately, with Mr. Justice LaForest's decision in Chan, our Supreme Court has clearly ruled out the approach taken by the BIA in re $R$ - $A$-, on the issue of voluntary association.

In order to avoid any confusion on this point, let me state incontrovertibly that a refugee alleging membership in a particular social group does not have to be in a voluntary association with other persons similar to him- or herself. Such a claimant is in no manner required to associate, ally, or consort voluntarily with kindred person. The association exists by virtue of a common attempt made by its members to exercise a fundamental human right. ${ }^{37}$

However, it is clear that the "voluntary association" problem is not the only difficult analytical problem that arises in gender-based claims. The dilemma of classifying the social-group category has also bedevilled the Immigration and Refugee Board in Canada. Here, because being part of the social group of women (who would fit the four criteria set out by the BIA) is not enough, claimants who are women have to show they are part of some particular sub-group of women..$^{38}$ This has led the Canadian Immigration and Refugee Board and the Federal Court to define particular social group in tortuous ways; "Women in China who have more than one child and face forced sterilization"; ${ }^{39}$ Trinidadian women subject to wife abuse"; 40 "New citizens of Israel who are women recently arrived from elements of the former Soviet Union and who are not yet well integrated into Israel society, despite the generous support offered by the Israeli government, who are lured into prostitution and threatened and exploited by individuals not connected to the government, and who can demonstrate indifference to their plight by front line authorities to whom they would normally be expected to turn to for protections"; ${ }^{41}$ "Women who have been subjected to exploitation resulting in the violation of the person and who, in consequences of the exploitation have been tried, convicted and sentenced to imprisonment." ${ }^{42}$

Such definitions, while they may benefit the individual claimants by recognizing their refugee status, do little to advance a comprehensive and consistent understanding 
of the refugee definition. Indeed, they create serious analytical difficulties. The BIA in re $R$ - $A$ - was rightly concerned about the characterization of the group in that case:

We find it questionable that the social group adopted by the Immigration Judge appears to have been defined principally, if not exclusively, for purposes of this asylum case, without regard to the question of whether anyone in Guatemala perceives this group to exist in any form whatsoever. ${ }^{43}$

In addition to this problem, gender-based socialgroup definitions often use the persecution experienced by the woman to define the particular social group, a process that leads inevitably to the circular reasoning described by Todd Stewart Schenk:

Grounds for asylum are established when an applicant proves persecution and connects that persecution to one of the five categories contained in the definition of refugee. This is a two-step approach. If a claimant attempts to define the particular social group of which she is a member in terms of persecution, as is the case when the particular social group is defined as "persecuted women," the argument takes on a circular characteristic. The claimant effectively argues that she is persecuted due to membership in a persecuted social group. What was initially a two-step approach is now a one-step approach. ${ }^{44}$

While the courts in Canada have for the most part accepted this circular reasoning to define social groups, it has not been without difficulty. Indeed, as early as 1992, the Federal Court of Appeal commented,

A question may be posed for the future: since, in this context, persecution must be feared by reason of membership in a particular social group, can fear of that persecution be the sole distinguishing factor that results in what is at most merely a social group becoming a particular social group? 45

Since Mayers was decided, the Canadian Supreme Court in Ward has clearly stated the characterization of a particular social group should not be made on the basis of the persecution feared, leaving open to attack all of these ingenious social-group formulations in gender cases, which are necessitated by our failure to recognize gender as an enumerated ground in its own right. ${ }^{46}$

Unfortunately, judicial supervision of the Canadian Convention Refugee Determination Division (CRDD) of the Immigration and Refugee Board is strictly limited. There is no statutory right of appeal from a negative refugee determination, only a limited judicial review with leave of the Federal Court. If leave is granted-and it is granted rarely - the standard of review for a CRDD deci- sion is "patently unreasonable." ${ }^{47}$ This means the court will determine only if the CRDD determination was reasonably open to it, not whether the CRDD interpretation of the Convention definition is strictly speaking correct. This limited review produces two distinct results for gender-based claims: few definitive pronouncements on the correct interpretation of the law, and conflicting CRDD interpretations of the law that are never reviewed. Unfortunately, successive law-student surveys of CRDD gender decisions clearly illustrate these consequences, as they show an inconsistent application of the gender guidelines, more influenced by preference of individual board member than consistent legal analysis. ${ }^{48}$ When coupled with the lack of judicial supervision, which might correct this inconsistency, there can be no doubt that problems exist for claimants making gender-based claims.

Many of the problems that arose in $r e R-A$-, and in others that we see here in Canada, would not arise if gender were a specific ground for claiming refugee status. If such a recognition were granted, no longer would refugee claimants have to show, on a case-by-case basis, that they are part of some exotic "particular social group," or that their battle against domestic abuse is part of a larger political struggle. The insistence upon the construction of new "particular social group" categories that can accommodate gender persecution, treats gender persecution as if it were somehow a temporary or isolated event, instead of the widespread, socially, culturally, and politically sanctioned persecution that it is.

While the 1991 un gender guidelines, and the Canadian and American guidelines that followed, were undoubtedly groundbreaking at the time, no one can argue that they have been entirely successful. The difficulties highlighted by In re $R$ - $A$ - and our own difficulties with circular reasoning, and the inconsistent application of the guidelines are but some of the problems. Notwithstanding the optimism of the Minister of Citizenship about the adequacy of the gender guidelines, these problems are symptomatic of the failure to recognize persecution on account of gender as a violation of human rights. Unfortunately, without recognition of gender as a sixth refugee category, these and other analytical problems will persist, inevitably compromising our ability to comprehensively protect refugee women.

The fiftieth anniversary of the UNHCR is perhaps an auspicious time to consider changing the refugee definition to explicitly add gender persecution. This change would bring the 1951 Convention definition of refugee in line with other Canadian and international human rights 
instruments that already recognize the importance of women's human rights. To add gender to the definition would formally recognize the worldwide systematic and institutionalized persecution of women on the basis of their gender and send a clear message that discriminatory treatment of women in the refugee process will no longer be tolerated.

\section{Notes}

1. Canadian Women's March Committee, "It's Time for Change: Demands to the Federal Government to End Poverty and Violence Against Women" (Toronto: Canadian Women's March Committee, 2000) at 31, recommendation 28.

2. See National Association of Women and the Law, West Coast Domestic Workers Association, La Table féministe francophone de concertation provinciale de l'Ontario, The National Organization of Immigrant and Visible Minority Women of Canada, Brief on the Proposed Immigration and Refugee Act, Bill C-31 Submitted to the Standing Committee on Citizenship and Immigration by Sharryn Aiken, André Côté, Audrey Macklin, Chantal Tie (National Association of Women and the Law, August 2000). See Bill C-11, s. 96.

3. Members of the Canadian Women's March Committee met with Elinor Caplan to discuss the immigration demands of the Women's March on October 16, 2000.

4. For a discussion of refugee statistics, see Monica Boyd, "Canada's Refugee Flows: Gender Inequality," on-line: Statistics Canada <http://www.statcan.ca/english/ads/11-0o8-XPE/ refugees.html > (date accessed: 20 January 2001.)

5. Office of the United Nations High Commissioner on Refugees, Guidelines on the Protection of Refugee Women, Doc. ES/ SCP/67 (1991).

6. Nada had refused to wear a veil in Saudi Arabia and wished to pursue a university education, in defiance of her father's wishes. She alleged that she was liable to public stoning in the streets by Saudi Arabia's unofficial religious police, if she was not veiled. She based her claim on a fear of persecution because she was a woman, because of her gender. In the original decision denying her claim for refugee status, the two Canadian board members, who were male, wrote that Nada "would do well to comply with the laws of her homeland ... and to show consideration for the feelings of her father, who opposed the liberalism of his daughter."

7. Guidelines issued by the chairperson pursuant to section 65(3) of the Immigration Act, R.S.C. 1985, chapter 31. Immigration and Refugee Board, "Women Refugee Claimants Fearing Gender-Related Persecution" (Ottawa: 1RB, 9 March 1993).

8. Phyllis Coven, "Immigration and Naturalization Service Gender Guidelines: Considerations for Asylum Officers Adjudicating Asylum Claims from Women" (1995) 7:4 Int. J. Ref. L. at 700 .

9. Interim Decision \#3403, at 30.

10. Karen Musalo, "Matter of R-A-: An Analysis of the Decisions and Its Implications," Interpreter Releases 76, no. 30, 9 August 1999; Karen Musalo, Gender-Based Asylum: An Analysis of Recent Trends 77, no. 42, 30 October 2000.

11. Musalo, Matter of R-A-, at 1186-87.

12. Supra note 9 at 7 and 8 .

13. Ibid. at 27.

14. Ibid. at 12-13.

15. "Criminal Injustice: Violence against Women in Brazil," Americas Watch (New York: Human Rights Watch, 1991).

16. Rhonda Copeland, "Recognizing the Egregious in the Everyday: Domestic Violence as Torture" (1994) 25 Colum. H.R.L. Rev. 291 at 305.

17. Supra note 9 at 43 .

18. Jim Martin Kwesi Mensah, IAD v 79-6136. FCA Decision A 524-80, and Manuel Jesus Torres Quinones, FCA (1982) 45 N.R., 602.

19. Guy Goodwin-Gill, The Refugee in International Law (Oxford: Clarendon Press, 1989) at 31.

20. Ward v. R. (Minister of Employment \& Immigration) 20 Imm.L.R. (2d) 85, at 126-30.

21. United Nations High Commissioner for Refugees, Handbook on Procedures and Criteria for Determining Refugee Status (Geneva: UNHCR, 1988) at 20, n. 42.

22. Doreen Indra, "A Key Dimension of the Refugee Experience" (1987) 6:3 Refuge.

23. In re $R-A-, 16$.

24. Supra note 9 at 28.

25. Supra note 16 at 304 .

26. S. Brownmiller, Against Our Will: Men, Women, and Rape (New York: Simon and Schuster, 1995).

27. Conway v. R., [1993] 2 S.C.R. 872, at 877, per LaForest J.; Oslin v. R., [193] 4 S.C.R. 595, at 669, per Cory J.; Janzen and Govereau v. Platy Enterprises Ltd. et al. [1989] 1 S.C.R. 1254, at 1284, per Dickson CJ.

28. The UNHCR Executive Committee Guidelines on Refugee Women discuss the symptoms of rape trauma syndrome as including "persistent fear, a loss of self-confidence and selfesteem, difficulty in concentration, an attitude of self-blame, a pervasive feeling of loss of control, and memory loss of distortion." See UNHCR Executive Committee Guidelines, Note on Women and International Protection, EC/CP/59 (28 August 1990) at 27.

29. Leanne Walker, Abused Women and Survivor Therapy: A Practical Guide for the Psychotherapist (Washington, DC: American Psychological Press, 1994) at 55.

30. In re $R-A-, 16$.

31. Ibid., 17.

32. Walker, Abused Women.

33. Ibid.

34. Supra note 9 at 11.

35. Department of Justice, Immigration, and Naturalization Service, 8CFr Part 208 [INS no. 2092-oo; AG order no. 2339-2000] RIN 1115-AF92. Federal Register: December 7, 2000 (vol. 65, no. 236) Proposed Rules, pp. 76588-76598. From the Federal Register online via GPO Access [wais.access.gpo.gov]. 
36. Department of Justice, Immigration and Naturalization Service, at 76595 .

37. Chan v. R. (Minister of Employment and Immigration), [1995] 3 S.C.R. 595.

38. See Mayers v. R. (Minister of Employment and Immigration) 97 D.L.R. (4th) 729, where in the context of the review of a credible basis hearing, the Federal Court of Appeal approved of an analysis that found that the social group of women, or Trinidadian women, do not constitute a particular social group, "constituting as they do about half of humanity."

39. Cheung v. R. (Minister of Employment and Immigration) (1993), 19 Imm.L.R. 81 (F.C.A.).

40. Mayers v. R. (Minister of Employment and Immigration) 97 D.L.R. (4th) 729.

41. Lithinov, Svetlans v. S.S.C. (F.C.T.D.) No. ImM-8488-93, Gibson, 30 June 1994.

42. Cen v. M.C.I. [1996] 1 F.C. 310 (T.D.).

43. In re $R-A-, 16$.

44. T.S. Schenk, "A Proposal to Improve the Treatment of Women in Asylum Law: Adding a 'Gender' Category to the International Definition of 'Refugee," online: Global Legal Studies Journal II <http://www.law.indiana.edu/glsj/vol2/schenk.html > (date accessed: 20 January 2001).

45. Supra note 37.

46. R. (A.G.) v. Ward [1993] 2 S.C.R. 689, at 729.

47. Sivasamboo v. R. (Minister of Citizenship and Immigration), [1995] 1 F.C. 741 (T.D.).

48. See Rell De Shaw, The Gender Guidelines Two Years On: Where Can We Go from Here? (1995) [unpublished student paper in hands of author]; Sylvia Valdman, The Immigration and Refugee Board Gender Guidelines and the Analysis of Culture and Gender at the Convention Refugee Determination Division (1996) [unpublished student paper in hands of author]; Student \#1049877, On Gender Persecution (1999) [unpublished student paper in hands of author]; Brigitte Chan Sui Hing, Gender-Related Persecution: A Look at the Past, Present and Future (1999) [unpublished student paper in hands of author].

Chantal Tie is executive director of South Ottawa Community Legal Services where she practises immigration and refugee law. She is also an adjunct professor at the University of Ottawa Law School, where she teaches immigration and refugee law.

(C) Chantal Tie, 2001. This open-access work is licensed under a Creative Commons Attribution-NonCommercial 4.0 International License, which permits use, reproduction and distribution in any medium for non-commercial purposes, provided the original author(s) are credited and the original publication in Refuge: Canada's Journal on Refugees is cited. 